\title{
Effect of elevated temperature on green gram [Vigna radiata (I).Wilczek] performance under temperature gradient tunnel (TGT) environment in Punjab
}

\author{
HARPREET SINGH, PRABHJYOT KAUR, S.K. BAL ${ }^{1 *}$ and B.U. CHOUDHURY ${ }^{2}$ \\ Department of Agricultural Meteorology, Punjab Agricultural University, Ludhiana, 141004, India; \\ ${ }^{1}$ ICAR-Central Research Institute for Dry Land Agriculture, Hyderabad, 500059, India; \\ ${ }^{2}$ ICAR-Research Complex for Northeast Hill Region, Umiam, 793103, India; \\ Corresponding author: santanu.bal@icar.gov.in
}

\begin{abstract}
Physiology of green gram is highly sensitive to fluctuations in the thermal environment. Abnormally high temperatures during pod setting to pod development stage induces reduction in pod setting, nonhealthy development and early maturity of grain which results in yield decline. We evaluated the effect of elevated temperatures in a Temperature Gradient Tunnel (TGT) on phenology, physiology and crop performance of green gram cultivars at semi-arid climate of Indian Punjab (Ludhiana). Five green gram cultivars were grown in TGT chambers in a factorial randomized block design with varying level of elevated temperatures $\left(+3.3^{\circ} \mathrm{C}\right.$ to $\left.5.2^{\circ} \mathrm{C}\right)$ for two consecutive kharif seasons $(2015-2016)$. The results reveal that the phenological stages of green gram, were advanced under elevated temperature within the TGT compared to open / ambient condition by 12-13 days. Maximum influence was observed in pod formation and pod maturity stages. With rise in temperatures by 3.3 to $5.2^{\circ} \mathrm{C}$ in TGT over ambient condition, the plant height increased but the number of branches per plant and the total above ground biomass as well as grain yield decreased consistently. It was found that with $1^{\circ} \mathrm{C}$ increase in average seasonal temperature, the grain yield decreased by $75 \mathrm{~kg} \mathrm{ha}^{-1}$. On the other hand, the harvest index was in general lower inside TGT chamber implying adverse influence of elevated temperature on biomass production although the partitioning of biomass was more efficient inside the TGT as evident from increase in harvest index. There was strong negative correlation of elevated temperature (inside TGT) with different yield attributes like 1000 seed weight, number of seeds per pod and number of pods per plant. Among the five green gram cultivars, ML-2037 was the most tolerant while cv. SML-1811 was the most susceptible to elevated temperature condition. In general, the grain yield decreased linearly with gradual increase in temperature. Average seasonal temperature of $29-30{ }^{\circ} \mathrm{C}$ may be considered as the favourable thermal conditions for the green gram crop in semi-arid conditions of Punjab. However, the future thrust will be to create more temperature gradients in the lower side so that the critical temperature threshold limits for optimum yield of green gram can be ascertained more accurately.
\end{abstract}

Keywords : Green gram, temperature gradient tunnel, growth, yield, yield attributes and elevated temperature.

Pulses are rich in proteins and found to be main source of protein to vegetarian people of India. It is the second important constituent of Indian diet after cereals. Green gram, one of the major pulse crops holds great significance in agriculture for its low requirement of inputs and its ability to restore soil fertility through symbiotic nitrogen fixation. The short crop duration and its wider adaptability to different environment and soil types make this crop important, particularly for resource poor farmers. In India, it is one of the important pulse crops having more than $60 \%$ and $50 \%$ of world's acreage and production, respectively. The area under this crop in India has increased from 1.99 to 4.31 million ha and production has increased from 0.60 to 2.07 million tonnes during 1964-65 to 2016 17.

The optimum temperature for potential yield of green gram lies between $28-30^{\circ} \mathrm{C}$. According to Aggarwal et al. (1977), green gram strains differ in their flowering response to photoperiod and to mean temperature. A temperature range of 27 to $32^{\circ} \mathrm{C}$ was found to be congenial for the reproductive development in green gram and increased temperature under delayed sowing significantly reduced the pod number (Tzudir et al., 2014). Michelle (2001-02) observed that $52 \%$ of the green gram seeds germinated at 32 ${ }^{\circ} \mathrm{C}$ while $43 \%$ of the seeds germinated at $21^{\circ} \mathrm{C}$ and none of the seeds germinated at $10^{\circ} \mathrm{C}$. In nodules, heat stress may 
either affect nitrogenase activity leading to decreased $\mathrm{N}$ fixation efficiency or accelerate nodule senescence resulting in reduced nodule longevity (Bordeleau and Prévost, 1994; Hungria and Vargas, 2000).

The low productivity of green gram can be ascribed to shorter crop duration and sensitivity to various abiotic stresses. Temperature is one of the major factors affecting the yield and quality of legumes including green gram. High temperature negatively affects photosynthesis, respiration, water relations and membrane stability, and also modulate levels of hormones, primary and secondary metabolites in field crops. Terminal heat and drought stress lead to flower drop and reduced yield (Singh et al., 2011). Increased flower shedding under high temperature, precipitation or desiccating winds during flowering period in legumes have also been reported in different studies (Sinha, 1977; Rainey and Griffiths, 2005). The low yield of this crop is due to the shedding of bud and flower resulting in low pod formation (Kumari and Varma, 1983). Significant flower shedding above $40^{\circ} \mathrm{C}$ in Green gram was reported by Khattak et al. (2009).

The rapid changes in climatic patterns in the recent years have made arid and semi-arid regions across the globe more vulnerable. Crops like green gram which is grown mostly in marginal lands and under rainfed conditions are therefore at higher risk. The country's productivity still remains low and therefore shortage of pulses will thus continue to be a cause of concern in the near future. Under high temperature induced atmospheric stress, the challenge to improve the crop productivity will be of an immense challenge for the farming community (Bal and Minhas, 2017). Therefore, it is imperative to generate information regarding sensitivity of green gram genotypes to higher temperature through screening and identifying suitable genotypes (Bal et al., 2018). Keeping the above facts in view, this study was conducted to evaluate five cultivars of green gramunder controlled elevated temperature conditions.

\section{MATERIALS AND METHODS}

\section{Study location}

The present investigation was carried out in a Temperature Gradient Tunnel (TGT) during kharif seasons for two consecutive years (2015 and 2016) at the Research Farm, Punjab Agricultural University, Ludhiana. The climate at Ludhiana is characterized as semi-arid with extreme winters and the soil type is of loamy-sand. The soil is medium in organic carbon, available nitrogen, phosphorous and potassium with neutral in $\mathrm{pH}$.

\section{Crop and plot details}

Five green gram cultivars (PAU-911, ML-818, ML2037, SML-1811 and ML-2056) were sown with row to row spacing of $30 \mathrm{~cm}$ and plant to plant spacing of $15 \mathrm{~cm}$ were grown in open and in Temperature Gradient Tunnel (TGT) that provides five elevated temperature regimes. Altogether there were 30 treatment combinations (6 temperature regimes $x 5$ varieties) grown in factorial randomized block design with three replications. The sowing was done on 7 July 2015 and 12 July 2016. The recommended doses of fertilizers (Nitrogen@11 kg per acre in form of urea and potassium @ $16 \mathrm{~kg} \mathrm{P}_{2} \mathrm{O}_{5}$ in form of muriate of potash)were applied at the time of sowing as per the package of practices of Punjab Agricultural University.

\section{Temperature gradient tunnel (TGT) structure}

The TGT, a tunnel like structure (Length-30m; width$5 \mathrm{~m}$; height $-3 \mathrm{~m}$ ) was fabricated using galvanized iron pipes frame and covered with UV stabilized polythene sheet having $85 \%$ transparency. Air inside the TGT was naturally warmed up by the incident solar radiation due to greenhouse effect making the inside air temperature higher as compared to that of outside. However, the TGT had cooling-pad at one end, on which water is sprinkled with a pump to produce a cool draft. Four exhaust fans were installed at the other end of TGT suck ambient air into tunnel through the cooling-pad to create variable thermal regimes (temperature gradient) along the whole length of the TGT. The inside of the tunnel was divided into 5 sections ( $5 \mathrm{~m}$ each) and 3 individual plots in a section representing as 3 replications. Each section represents one level of temperature along the gradient. One set of temperature and Relative humidity sensors were installed at each section within TGT to record the daily progress of temperature and relative humidity during the crop season (Fig. 1). One set of temperature and relative humidity sensors were also installed outside the TGT to monitor the ambient air outside the TGT. The data was monitored by the data logger (Delta-T devices make) at five minutes interval and recorded at half-hour interval.

\section{Elevated temperature treatment detail}

The experiment on green gram crop was performed with one ambient temperature $\left(\mathrm{S}_{1}\right)$ outside TGT and five levels of elevated temperatures $\left({ }^{\circ} \mathrm{C}\right)$ inside TGT namely +3.3 $\left(\mathrm{S}_{2}\right),+3.9\left(\mathrm{~S}_{3}\right),+4.1\left(\mathrm{~S}_{4}\right),+4.3\left(\mathrm{~S}_{5}\right),+4.8\left(\mathrm{~S}_{6}\right)$ during 2015 and similarly one outside $\mathrm{S}_{1}$ (ambient) and five inside TGT +3.9 
Table 1: Effect of different elevated temperature regimes (inside TGT) on growth attributes of mungbean cultivars during $k$ harif 2015

\begin{tabular}{|c|c|c|c|c|c|c|}
\hline \multirow[t]{2}{*}{ Treatments } & \multicolumn{3}{|c|}{ Plant height } & \multicolumn{3}{|c|}{ Number of branches per plant } \\
\hline & $30 \mathrm{DAS}$ & 45 DAS & $60 \mathrm{DAS}$ & $30 \mathrm{DAS}$ & $45 \mathrm{DAS}$ & $60 \mathrm{DAS}$ \\
\hline \multicolumn{7}{|c|}{ Elevated temperature gradient $\left({ }^{\circ} \mathrm{C}\right)$} \\
\hline $\mathrm{S}_{0}: 29.6(\mathrm{Ta})$ & 35.9 & 50.1 & 79.2 & 6.3 & 8.2 & 8.6 \\
\hline $\mathrm{S}_{1}: \mathrm{Ta}+3.3$ & 31.1 & 44.3 & 68.2 & 5.7 & 7.7 & 8.5 \\
\hline $\mathrm{S}_{2}: \mathrm{Ta}+3.9$ & 31.2 & 45.5 & 70.4 & 5.3 & 7.5 & 8.3 \\
\hline $\mathrm{S}_{3}: \mathrm{Ta}+4.1$ & 32.6 & 45.5 & 70.8 & 5.4 & 7.3 & 7.8 \\
\hline $\mathrm{S}_{4}: \mathrm{Ta}+4.3$ & 33.1 & 46.4 & 73.9 & 5.2 & 7.2 & 7.7 \\
\hline $\mathrm{S}_{5}: \mathrm{Ta}+4.8$ & 33.9 & 47.6 & 75.6 & 5.0 & 7.1 & 7.4 \\
\hline $\mathrm{CD}(P=0.05)$ & 0.77 & 1.5 & 3.6 & 0.18 & 0.19 & 0.18 \\
\hline \multicolumn{7}{|l|}{ Cultivar } \\
\hline PAU 911 & 30.8 & 42.9 & 66.4 & 4.9 & 6.8 & 7.7 \\
\hline ML 818 & 32.7 & 46.1 & 72.9 & 5.1 & 7.2 & 7.8 \\
\hline ML 2037 & 32.4 & 44.7 & 72.4 & 5.6 & 7.7 & 8.5 \\
\hline SML 1811 & 29.8 & 49.7 & 62.2 & 4.6 & 6.6 & 7.4 \\
\hline ML 2056 & 30.7 & 42.5 & 66.1 & 5.3 & 7.3 & 8.2 \\
\hline $\mathrm{CD}(P=0.05)$ & 0.66 & 1.3 & 3.2 & 0.11 & 0.17 & 0.17 \\
\hline $\mathrm{CD}($ temp x cultivar) at $P=0.05$ & 1.62 & 3.4 & 4.1 & NS & NS & NS \\
\hline
\end{tabular}

Note: $\mathrm{Ta}=$ Ambient temperature, outside the Temperature Gradient Tunnel

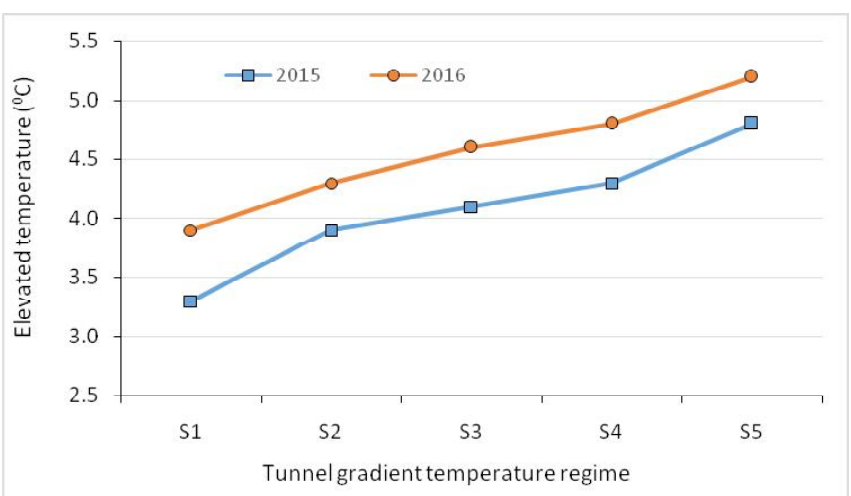

Fig.1: Elevated temperature (TGT temp-Ambient temp) regimes within theTGTduring the crop growing seasons (2015 and 2016)

$\left(\mathrm{S}_{2}\right),+4.3\left(\mathrm{~S}_{3}\right),+4.6\left(\mathrm{~S}_{4}\right),+4.8\left(\mathrm{~S}_{5}\right),+5.2\left(\mathrm{~S}_{5}\right)$ during 2016. Five thermal sensors were installed inside the tunnels at $S_{2}$, $\mathrm{S}_{3}, \mathrm{~S}_{4}, \mathrm{~S}_{5}$ and $\mathrm{S}_{6}$ separated by $1 \mathrm{~m}$ between two levels. The $\mathrm{S}_{2}$ was installed near the cooling pad of the tunnel, while $S_{6}$ was near the outlet point. However, the seasonal temperature outside tunnel was $29.6^{\circ} \mathrm{C}$ and $29.8^{\circ} \mathrm{C}$ for the crop seasons of 2015 and 2016, respectively.

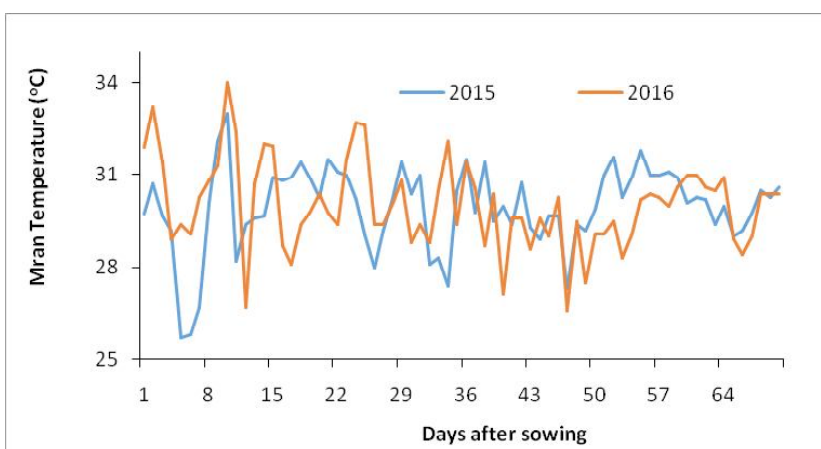

Fig. 2: Progress of daily ambient mean temperature $\left({ }^{\circ} \mathrm{C}\right)$ during the crop growing phase in 2015 and 2016 at study site

\section{Crop observations}

The duration of crop phenological stages e.g., flower initiation $(\mathrm{P} 1), 50 \%$ flowering $(\mathrm{P} 2)$, start pod formation $(\mathrm{P} 3)$, pod filling and physiological maturity (P5) were recorded. The periodic data on plant height, number of branches/plant and LAI were recorded at 30 days interval from the tagged plants in two replications after sowing of the crop. At 
Table 2: Effect of different elevated temperature regimes (inside TGT) on growth attributes of mungbean cultivars during kharif 2016

\begin{tabular}{|c|c|c|c|c|c|c|}
\hline \multirow[t]{2}{*}{ Treatments } & \multicolumn{3}{|c|}{ Plant height } & \multicolumn{3}{|c|}{ Number of branches per plant } \\
\hline & $30 \mathrm{DAS}$ & $45 \mathrm{DAS}$ & $60 \mathrm{DAS}$ & $30 \mathrm{DAS}$ & 45 DAS & $60 \mathrm{DAS}$ \\
\hline \multicolumn{7}{|c|}{ Elevated temperature gradient $\left({ }^{\circ} \mathbf{C}\right)$} \\
\hline $\mathrm{S}_{0}: 29.8(\mathrm{Ta})$ & 41.2 & 68.8 & 88.8 & 5.9 & 7.8 & 7.8 \\
\hline $\mathrm{S}_{1}: \mathrm{Ta}+3.9$ & 31.6 & 31.6 & 71.1 & 5.3 & 7.1 & 7.1 \\
\hline $\mathrm{S}_{2}: \mathrm{Ta}+4.3$ & 36.6 & 36.6 & 77.8 & 5.1 & 6.9 & 6.9 \\
\hline $\mathrm{S}_{3}: \mathrm{Ta}+4.6$ & 36.7 & 36.7 & 81.5 & 4.9 & 6.8 & 6.8 \\
\hline $\mathrm{S}_{4}: \mathrm{Ta}+4.8$ & 37.6 & 37.6 & 82.7 & 4.8 & 6.6 & 6.6 \\
\hline $\mathrm{S}_{5}: \mathrm{Ta}+5.2$ & 37.8 & 37.8 & 84.4 & 4.5 & 6.5 & 6.5 \\
\hline $\mathrm{CD}(P=0.05)$ & 2.8 & 1.8 & 1.9 & 0.19 & 0.12 & 0.12 \\
\hline \multicolumn{7}{|l|}{ Cultivar } \\
\hline PAU 911 & 33.4 & 61.8 & 77.3 & 4.5 & 6.3 & 7.3 \\
\hline ML 818 & 34.8 & 63.8 & 80.4 & 4.7 & 6.6 & 7.4 \\
\hline ML 2037 & 34.6 & 63.6 & 77.5 & 5.3 & 7.2 & 8.1 \\
\hline SML 1811 & 31.9 & 57.0 & 73.5 & 4.3 & 6.1 & 7.0 \\
\hline ML 2056 & 33.3 & 59.2 & 74.1 & 4.9 & 6.8 & 7.8 \\
\hline $\mathrm{CD}(P=0.05)$ & NS* & 1.6 & 1.7 & 0.17 & 0.11 & 0.14 \\
\hline $\mathrm{CD}$ (temp x cultivar) at $P=0.05$ & 2.4 & 4.1 & 4.3 & NS & NS & NS \\
\hline
\end{tabular}

Note: $\mathrm{Ta}=$ Ambient temperature, outside the Temperature Gradient Tunnel

maturity, yield and yield attributes (plant height, pod per plant, number of grains per pod, 100 grain weight, grain yield and biomass yield, harvest index) were recorded.

\section{Statistical analysis}

Analysis of variance (ANOVA) was done to compare the treatment effects and linear regression analysis done to analyze the impact of elevated temperature on crop growth and development by following the standard statistical procedures (Panse and Sukhatme, 1967). As the temperature regimes in during two study years were not identical the pooeld analysis was not done. Furthermore, there was $15 \%$ difference in radiation receipt between inside and outside TGT. Hence, for linear regression study only the TGT treatments of both the years were considered to avoid the effect differences in radiation regime between inside and outside TGT treatments.

\section{RESULTS AND DISCUSSION}

The average temperature gradient was $+3.3,+3.9$, $+4.1,+4.3$ and $+4.8^{\circ} \mathrm{C}$ in 2015 and $+3.9,+4.3,+4.6,+4.8$ and $+5.2^{\circ} \mathrm{C}$ in 2016 where three levels of temperature i.e., +3.9 , +4.3 and $+4.8^{\circ} \mathrm{C}$ were common for both years (Fig. 1).

\section{Phenological response}

The phenological calendar of green gram cultivars PAU-911, ML-818, ML-2037, SML-1811 and ML-2056 inside TGT and ambient condition for both years is presented in Fig. 4. The crop duration of green gram reduced with increase in temperatures in all the varieties. Crop sown under TGT took 12-13 days less as compared to ambient conditions to achieve different physiological events for both the years. Green gram cultivars took 62-67 days to reach physiological maturity under TGT during both the years. The crop duration was minimum in $+4.8^{\circ} \mathrm{C}$ environment and gradually increased with lower temperature conditions. As the average temperature of entire 2015 crop season was lesser than 2016 crop season, it resulted in the crop to mature late in 2016 (79 days) as compared to 2015 ( 76 days). Earlier studies have also shown that warmer temperature hastened the crop development and shortened the growth period (Sadras and Mazon, 2006; Tao et al., 2006; Challinor and Wheeler, 2008). Among the cultivars, it was found that the window for crop maturity was narrow for variety ML2037 as compared to in stressed conditions. This signifies its better adaptability under heat stress conditions. 

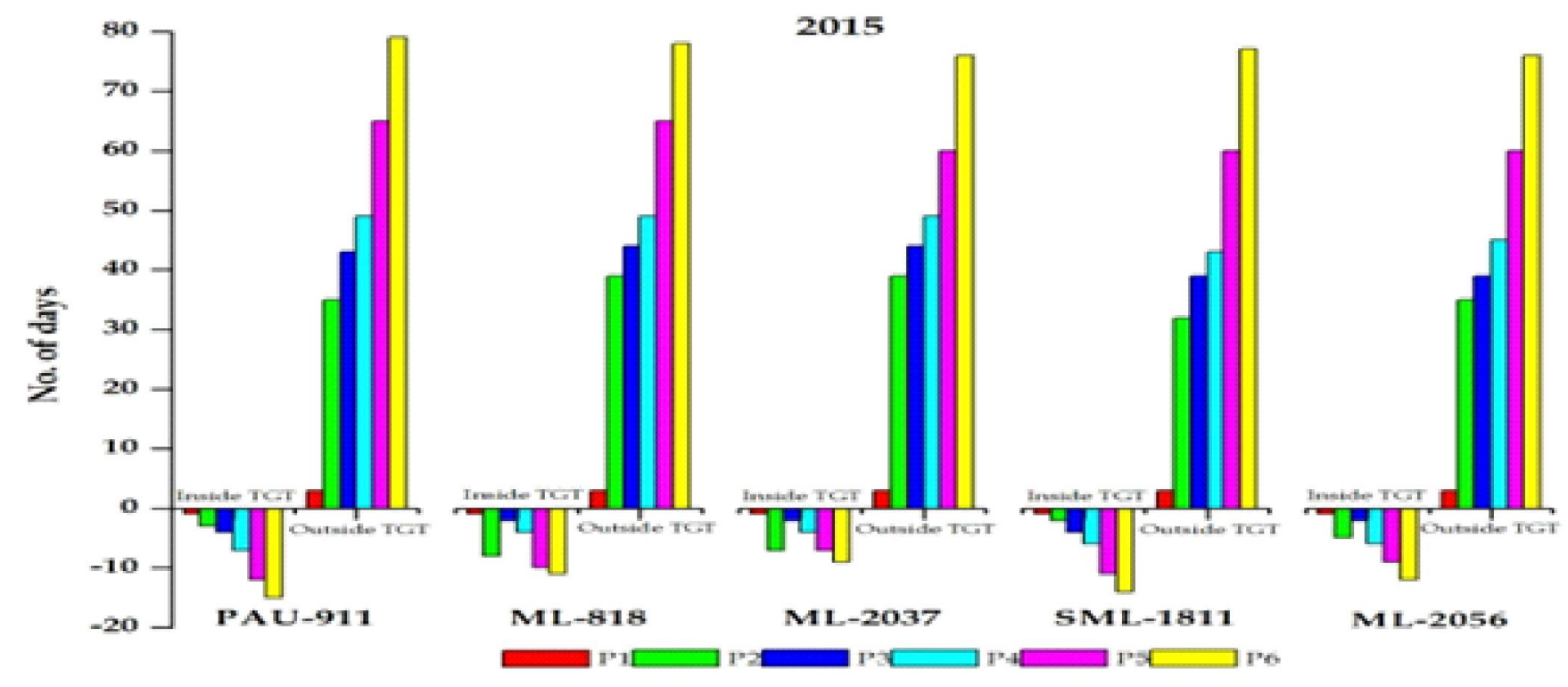

$-20]$ PAU-911

ML-2056
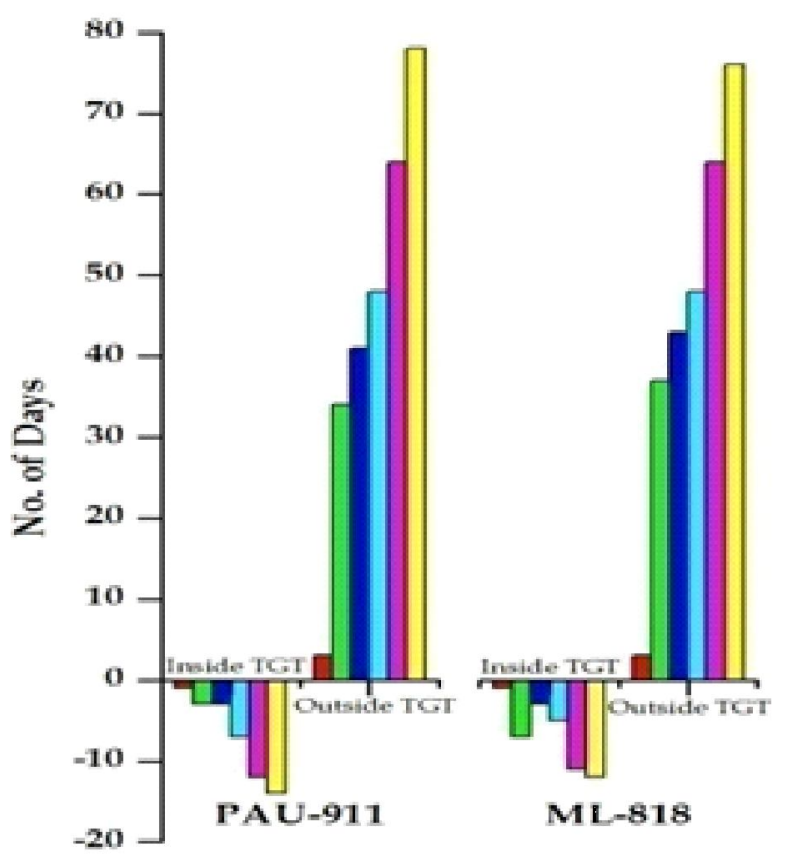

\section{6}

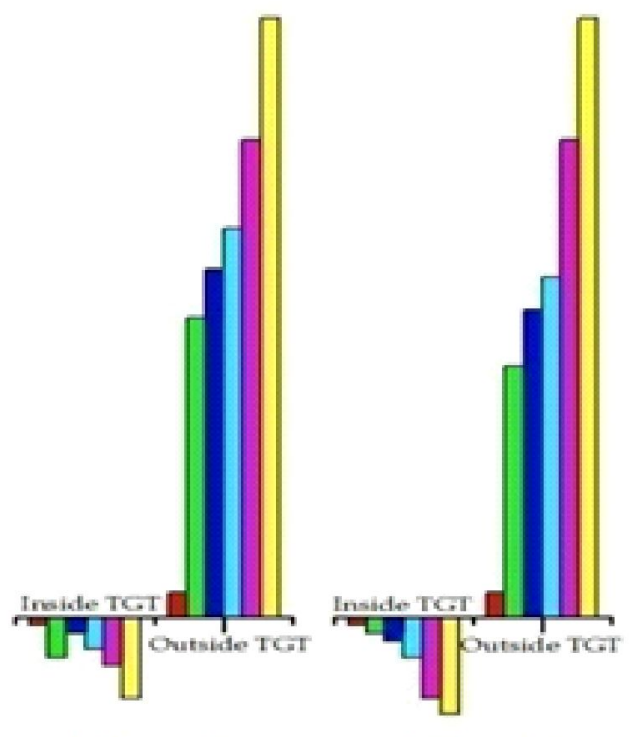

ML-2037

SML-1811

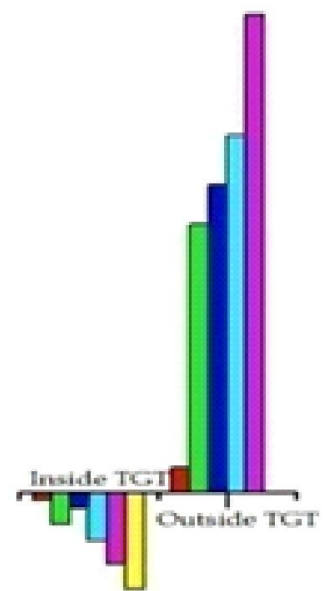

ML-2056

Fig. 3: Effect of elevated temperature on the phenology of five green gram cultivars in the year 2015 and 2016 (The phonological duration inside TGT expressed as deviation from ambient condition) [P1: flower initiation (P1), P2: $50 \%$ flowering (P2), P3: start pod formation (P3), $\mathrm{P} 4$ : pod filling and P5: physiological maturity (P5)]

\section{Leaf area index (LAI)}

Amongst the cultivars, the decrease in LAI was maximum in SML-1811 (2.2) followed by that of PAU-911 (2.5), ML-818 (2.7), ML-2056 (2.8) and ML-2037 (3.1) in crop seasons 2015 and 2016 (Fig. 5) in both open and TGT chambers under elevated temperature condition. In all the cultivars, leaf area of the crop decreased with increase in temperature. The variability in leaf area under TGT was more pronounced as compared to open condition. Earlier studies indicated that the initiation and expansion of roots, leaves, shoots, tillers, branches and reproductive organs are strongly driven by temperature (Morrison and Lawlor, 1999) and warmer condition both accelerated rate of organ initiation and shortened duration of organ growth, thereby leading to 
Table 3: Effect of elevated temperature regimes (inside TGT) on yield and yield components of mungbean cultivars during kharif, 2015

\begin{tabular}{|c|c|c|c|c|c|c|}
\hline Treatments & $\begin{array}{l}\text { Grain yield } \\
\left(\mathrm{kg} \mathrm{ha}^{-1}\right)\end{array}$ & $\begin{array}{l}\text { Biomass } \\
\text { yield }\left(\mathrm{kg} \mathrm{ha}^{-1}\right)\end{array}$ & $\begin{array}{l}\text { Seeds per } \\
\text { pod }\end{array}$ & $\begin{array}{l}\text { Pods per } \\
\text { plant }\end{array}$ & $\begin{array}{l}1000 \text { grain } \\
\text { weight }(\mathrm{g})\end{array}$ & $\begin{array}{l}\text { Harvest } \\
\text { index }(\%)\end{array}$ \\
\hline \multicolumn{7}{|l|}{ Elevated temperature gradient $\left({ }^{\circ} \mathbf{C}\right)$} \\
\hline $\mathrm{S}_{0}: 29.6(\mathrm{Ta})$ & 1040.0 & 4631.6 & 10.9 & 44.3 & 42.7 & 22.3 \\
\hline $\mathrm{S}_{2}: \mathrm{Ta}+3.3$ & 758.3 & 2998.3 & 10.2 & 27.6 & 35.6 & 25.7 \\
\hline $\mathrm{S}_{3}: \mathrm{Ta}+3.9$ & 745.8 & 2879.9 & 9.8 & 25.5 & 34.1 & 25.6 \\
\hline $\mathrm{S}_{4}: \mathrm{Ta}+4.1$ & 706.6 & 2292.4 & 9.5 & 22.8 & 32.0 & 30.6 \\
\hline $\mathrm{S}_{5}: \mathrm{Ta}+4.3$ & 683.3 & 2163.3 & 9.4 & 21.6 & 31.0 & 31.2 \\
\hline $\mathrm{S}_{5}: \mathrm{Ta}+4.8$ & 650.8 & 2112.8 & 9.2 & 20.4 & 29.3 & 30.7 \\
\hline $\mathrm{CD}(P=0.05)$ & 31.8 & 72.7 & 0.27 & 1.7 & 1.5 & 2.1 \\
\hline \multicolumn{7}{|l|}{ Cultivar } \\
\hline PAU 911 & 720.8 & 2728.4 & 9.4 & 23.2 & 32.2 & 26.4 \\
\hline ML 818 & 763.2 & 2874.2 & 10.1 & 26.0 & 34.3 & 27.5 \\
\hline ML 2037 & 843.7 & 3122.9 & 10.6 & 32.4 & 37.2 & 27.9 \\
\hline SML 1811 & 701.3 & 2466.6 & 9.0 & 23.9 & 30.9 & 28.9 \\
\hline ML 2056 & 791.6 & 3042.3 & 10.3 & 29.5 & 36.1 & 27.7 \\
\hline $\mathrm{CD}(P=0.05)$ & 29.1 & 66.4 & 0.25 & 1.6 & 1.4 & NS \\
\hline $\mathrm{CD}$ (temp x cultivar) at $P=0.05$ & NS & 162 & NS & NS & NS & NS \\
\hline
\end{tabular}

Note: $\mathrm{Ta}=$ Ambient temperature, outside the Temperature Gradient Tunnel

reduced growth of plants at higher temperature. Shah and Paulsen (2003) also stated that high temperature adversely affected photosynthesis in wheat.

\section{Plant height}

The comparison among the varieties shows that the variety ML818 recorded maximum plant height in both 2015 and 2016 whereas the var, SML1811 recorded the lowest plant height. The plant height was significantly higher under ambient condition than under elevated temperature regimes (Table 2). The plant height increased maximum up to $60 \mathrm{DAS}$ in ambient temperature regimes and decreased by 4.7, 7.1, 9.2, 11.8 and $17.1 \%$ with increase in mean elevated temperature of two crop seasons by +3.9 , +4.3 and $+4.8{ }^{\circ} \mathrm{C}$, respectively. The analysis showed that although the ambient temperature condition recorded higher plant height, there was strong positive correlation between air temperature and plant height $(\mathrm{P}<0.001)$ inside TGT (Fig. $5 \mathrm{~A})$. While under open condition the plants get ample amount light for higher growth and plant height, the plants inside TGT received $15 \%$ less light. However, under reduced light condition higher thermal regime has led to increase plant height. The interaction effect of thermal regime and cultivar was significant with respect to plant height with rate of decrease minimum (4.7\%) and maximum (17.1\%) for varieties ML 2037 and SML 1811, respectively.

\section{Number of branches per plant}

The analyzed data reveal that number of branches per plant was significantly higher under ambient conditions as compared to elevated temperature regimes. Compared to ambient temperature, the reduction in number of branches per plant was 3.5 to $14.1 \%$ under elevated temperatures during the two crop seasons. It was also revealed that, under elevated temperature regimes during two crop seasons, the number of branches was maximum in cultivar ML-2037 (5.4) followed by ML-2056 (5.1), ML-818 (4.9), PAU-911 (4.7), SML-1811 (4.5), respectively. However, the interaction effect of cultivar and elevated temperature was statistically non-significant.

\section{Biomass yield}

Rise in temperature inside the TGT caused significant reduction in biomass in both the crop seasons. The biomass yield was about 1.6 times higher under ambient conditions $\left(4631.6 \mathrm{kgha}^{-1}\right)$ as compare to elevated temperature regimes 
Table 4: Effect of elevated temperature regimes (inside TGT) on yield and yield components of mungbean cultivars during kharif, 2016

\begin{tabular}{|c|c|c|c|c|c|c|}
\hline Treatments & $\begin{array}{l}\text { Grain yield } \\
\left(\mathrm{kg} \mathrm{ha}^{-1}\right)\end{array}$ & $\begin{array}{l}\text { Biomass yield } \\
\left(\mathrm{kg} \mathrm{ha}^{-1}\right)\end{array}$ & $\begin{array}{l}\text { Seeds per } \\
\text { pod }\end{array}$ & $\begin{array}{l}\text { Pods per } \\
\text { plant }\end{array}$ & $\begin{array}{l}1000 \text { grain } \\
\text { weight }(\mathrm{g})\end{array}$ & $\begin{array}{l}\text { Harvest } \\
\text { index }(\%)\end{array}$ \\
\hline \multicolumn{7}{|c|}{ Elevated temperature gradient $\left({ }^{\circ} \mathrm{C}\right)$} \\
\hline $\mathrm{S}_{0}: 29.8(\mathrm{Ta})$ & 1036.6 & 4549.1 & 10.8 & 39.4 & 40.7 & 22.8 \\
\hline $\mathrm{S}_{1}: \mathrm{Ta}+3.9$ & 771.6 & 2899.9 & 10.1 & 27.3 & 36.5 & 26.1 \\
\hline $\mathrm{S}_{2}: \mathrm{Ta}+4.3$ & 738.3 & 2790.8 & 9.8 & 25.8 & 34.3 & 26.7 \\
\hline $\mathrm{S}_{3}: \mathrm{Ta}+4.6$ & 699.1 & 2234.9 & 9.2 & 23.0 & 30.8 & 31.8 \\
\hline $\mathrm{S}_{4}: \mathrm{Ta}+4.8$ & 672.4 & 2129.1 & 9.1 & 22.5 & 29.2 & 32.3 \\
\hline $\mathrm{S}_{5}: \mathrm{Ta}+5.2$ & 647.4 & 2056.6 & 8.8 & 20.1 & 26.8 & 31.8 \\
\hline $\mathrm{CD}(P=0.05)$ & 30.5 & 73.4 & 0.32 & 1.6 & 1.95 & 1.9 \\
\hline \multicolumn{7}{|l|}{ Cultivar } \\
\hline PAU 911 & 700.6 & 2656.6 & 9.1 & 24.7 & 31.1 & 28.3 \\
\hline ML 818 & 773.6 & 2811.1 & 9.8 & 25.4 & 32.6 & 27.7 \\
\hline ML 2037 & 840.2 & 3043.7 & 10.4 & 30.9 & 36.0 & 28.7 \\
\hline SML 1811 & 619.3 & 2406.9 & 9.1 & 23.4 & 31.1 & 31.1 \\
\hline ML 2056 & 815.9 & 2956.9 & 9.9 & 28.1 & 34.3 & 27.5 \\
\hline $\mathrm{CD}(P=0.05)$ & 27.8 & 67.1 & 0.30 & 1.5 & 1.8 & 1.8 \\
\hline $\mathrm{CD}$ (temp x cultivar) at $P=0.05$ & NS & 164 & NS & NS & NS & NS \\
\hline
\end{tabular}

Note: $\mathrm{Ta}=$ Ambient temperature, outside the Temperature Gradient Tunnel

in both 2015 and 2016. The analysis revealed that biomass yield $\left(\mathrm{kgha}^{-1}\right)$ was reduced by $37.0,46.0$ and $53.8 \%$ with increase in mean elevated temperature for two crop seasons of $3.9,4.3$ and $4.8^{\circ} \mathrm{C}$, respectively from ambient condition. Among the cultivars the biomass yield under elevated temperature regimes decreased maximum in cultivar SML1811 (2466.6 and $2406.9 \mathrm{kgha}^{-1}$ in 2015 and 2016, respectively). However, the decrease was minimum for the variety ML 2037 (3122.9 and $3043.7 \mathrm{kgha}^{-1}$ in 2015 and 2016, respectively). The interaction effect of the elevated regimes was statisticallynon-significant. Similar results on decrease in biomass yield of green gram under elevated temperature have been reported by Khattak et al., (2009) and Islam, (2014).

\section{Grain yield}

Grain yield was significantly higher under ambient temperature conditions as compared to different elevated temperature regimes (Table 3 ). The results revealed that amongst the cultivars, ML-2037 (842 $\left.\mathrm{kgha}^{-1}\right)$ was most tolerant and cv. SML-1811 (688 $\left.\mathrm{kg} \mathrm{ha}^{-1}\right)$ was the most susceptible to increased temperature. The analysis of both years data revealed that the grain yield was decreased by
$26.9,31.5$ and $36.2 \%$ with increase in mean elevated temperature by $3.9,4.3$ and $4.8^{\circ} \mathrm{C}$, respectively from ambient conditions. However, grain yield was in general higher in 2015 crop season as compared to that of 2016 due to favourable conditions during 2015 growing season. The data analysis for the two years reveal that beyond $29.7^{\circ} \mathrm{C}$, the grain yield decreased by $75 \mathrm{~kg}$ per $1{ }^{\circ} \mathrm{C}$ increase in average temperature during the growing season. There was strong negative correlation $(\mathrm{P}<0.001)$ between air temperature and grain yield while considering the treatments inside TGT for both the years of study (Fig. 5C). Similar results were also reported by Araujo et al., (2015), Khattak et al., (2009), Singh and Singh, (2011).

\section{Vield components}

Different yield components like number of pods per plant, number of seeds per pod, 1000 seed weight were analyzed to find the effect of elevated temperature in 2015 and 2016 (Table 3 and 4 respectively). The study of the two years data revealed that the numbers of pod per plant and 1000 seed weight were more in 2015 as compared to 2016 crop season. While the effect of elevated temperature and variety as main factors were statistically significant the 

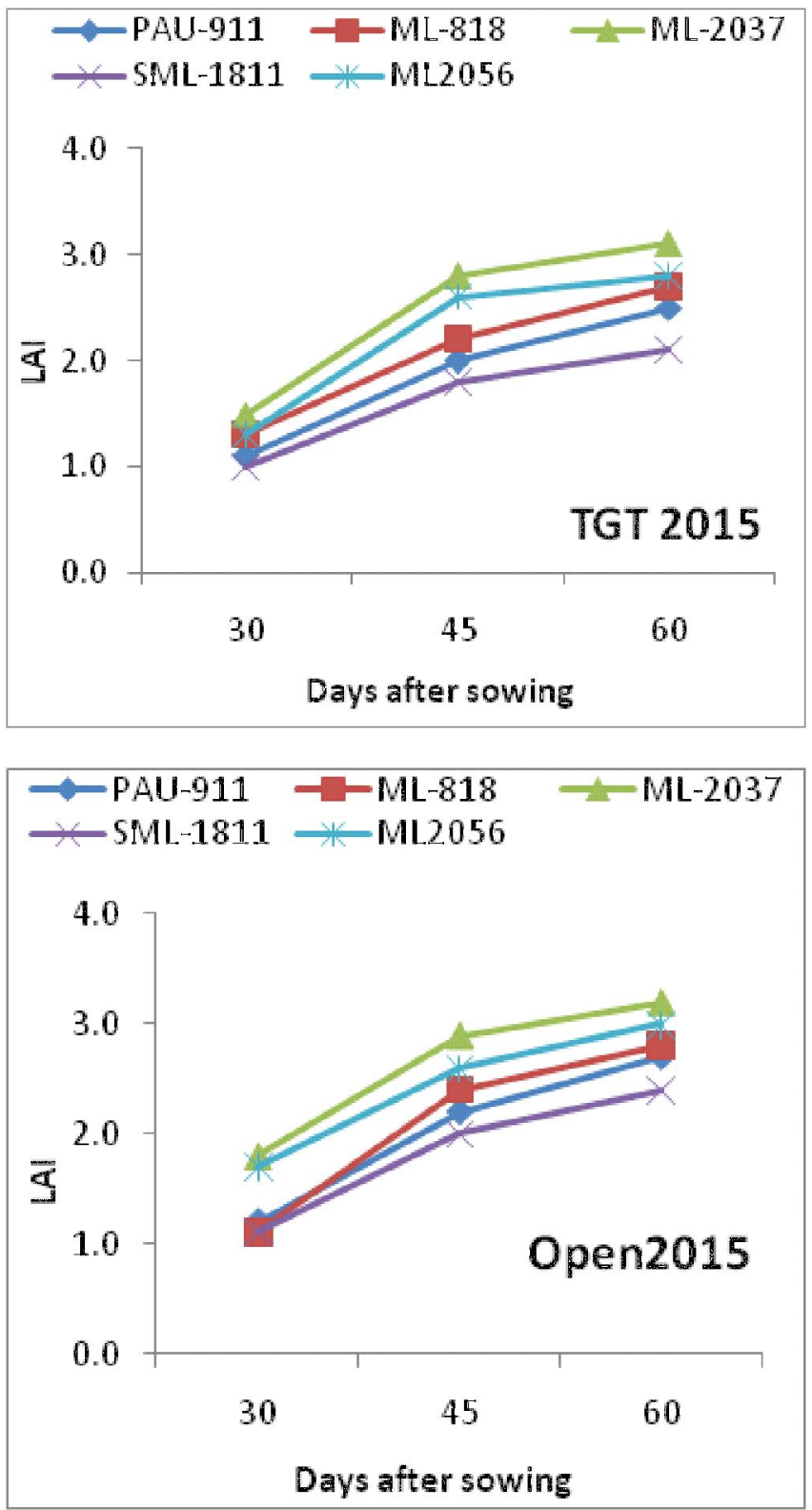

Fig. 4: Variation in periodic LAI of green gram cultivars under open and TGT environments during 2015 and 2016 interaction effect of temperature and variety was statistically non-significant for all the yield components.

The number of seeds per pod, number of pods per plant and 1000 seed weight were significantly higher under ambient environment as compared to elevated temperature regimes. The trend shows that the number of pods per plant was reduced from ambient temperature regimes by 36.8 , 43.3 and $48.6 \%$ with increase in mean elevated temperature for two crop seasons by $3.9,4.3$ and $4.8{ }^{\circ} \mathrm{C}$, respectively. Similarly, 1000 grain weight was reduced from ambient temperature regime by $15.3,21.8$ and $30.0 \%$ with increase in mean elevated temperature for two crop seasons by 3.9 , 4.3 and $4.8^{\circ} \mathrm{C}$, respectively whereas decrease in number of

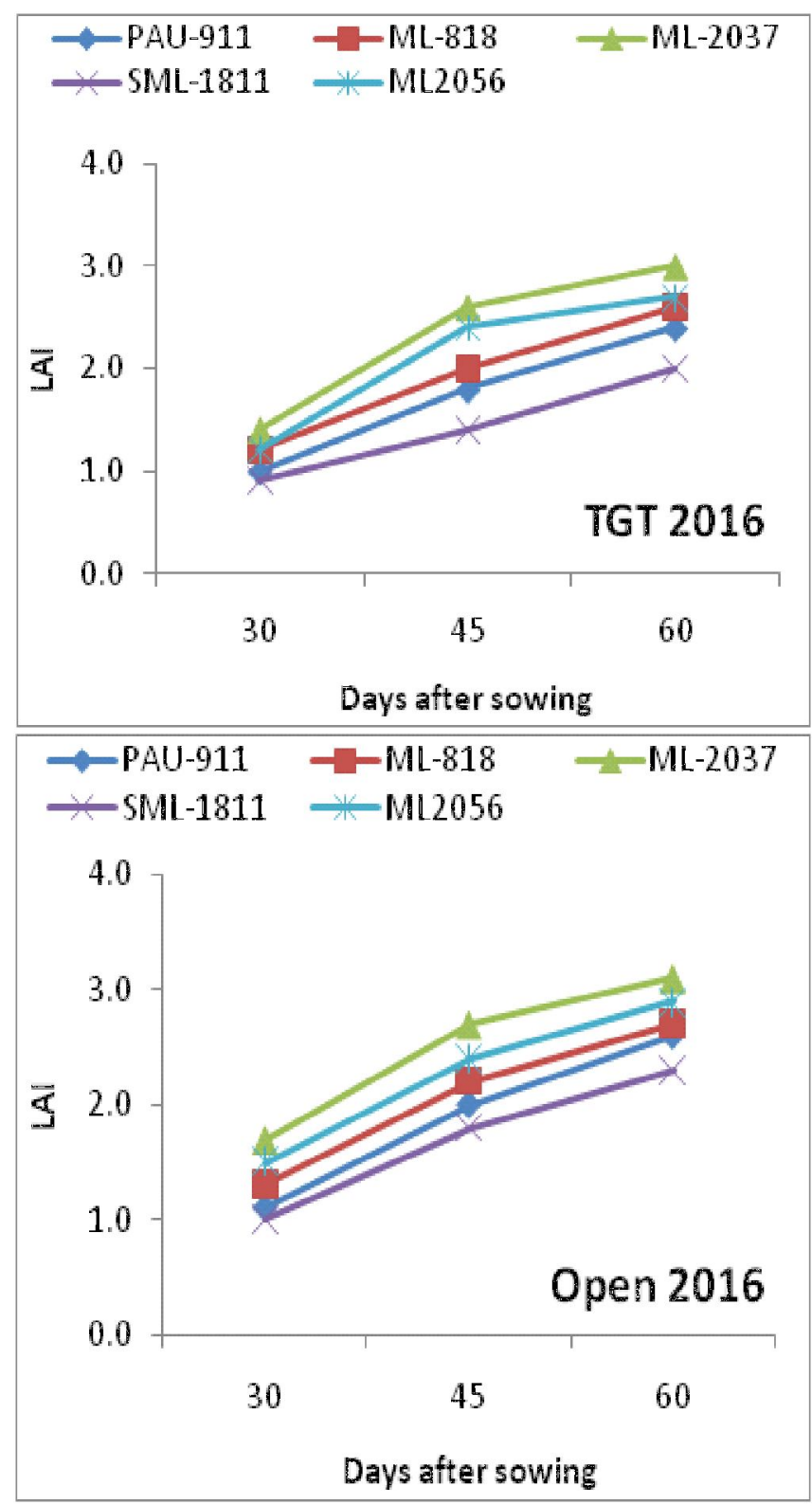

seeds per pod by $8.3,11.9$ and $16.5 \%$ with increase in mean elevated temperature for two crop seasons by 3.9, 4.3 and $4.8^{\circ} \mathrm{C}$, respectively from ambient condition. Using both years' data inside the TGT we found strong negative correlation of temperature regime with number of seeds per pod (Fig. 5D) and 1000 seed weight (Fig. 5E)

The perusal of the data revealed that all the yield attributes namely, number of pods per plant, number of seeds per pod and 1000 seed weight under elevated temperature regimes were decreased from the ambient conditions to maximum extent in cultivar SML-1811 followed by PAU-911, ML-818, ML-2056 and ML-2037 in the givenorder. 


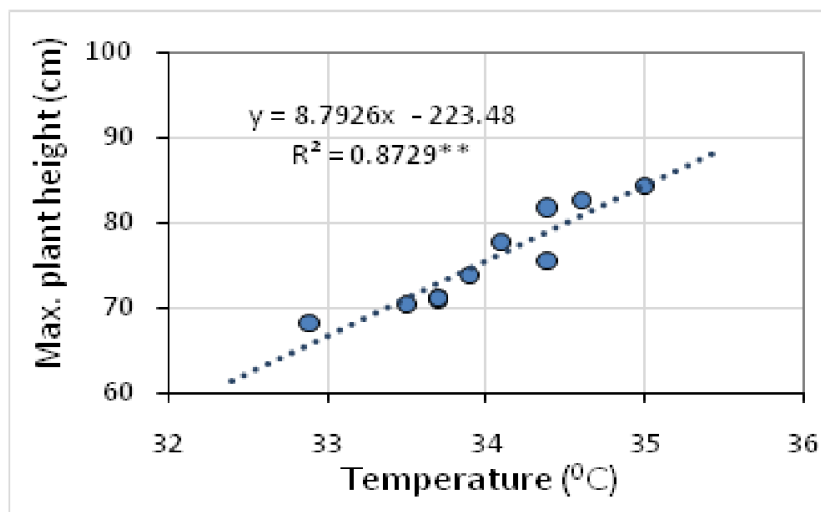

A) Temperature vs maximum plant height

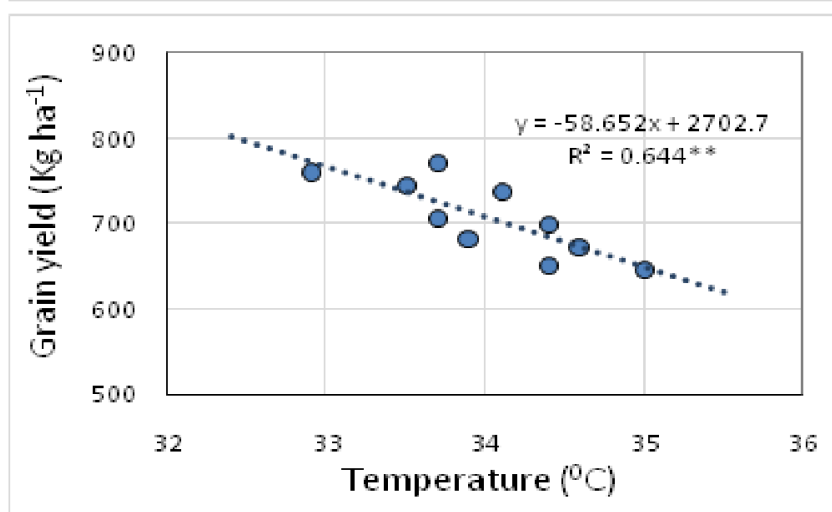

c) Temperature vs Grain yield

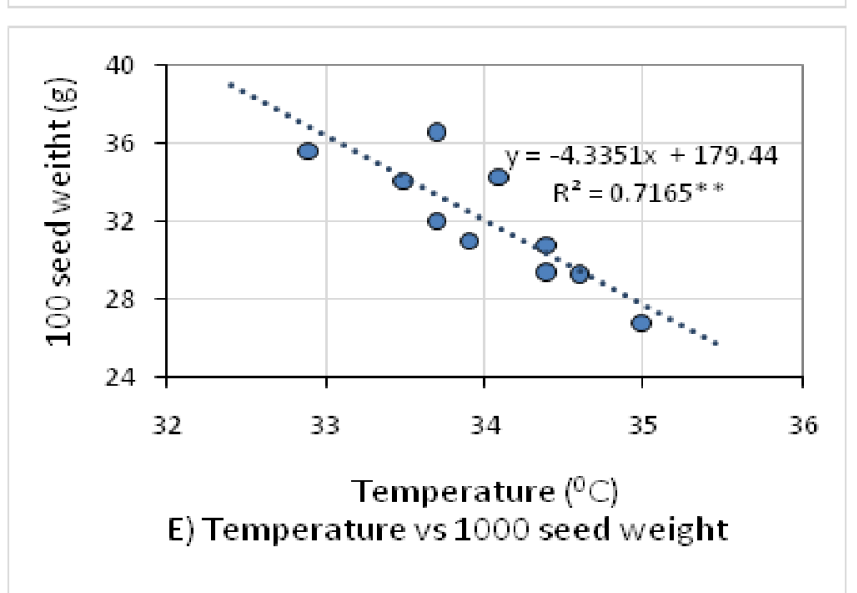

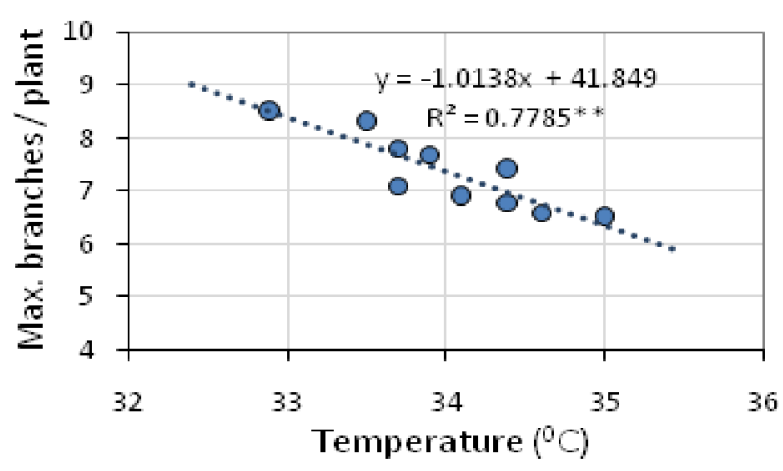

B) Temperature vs maximum No. of branches per plant
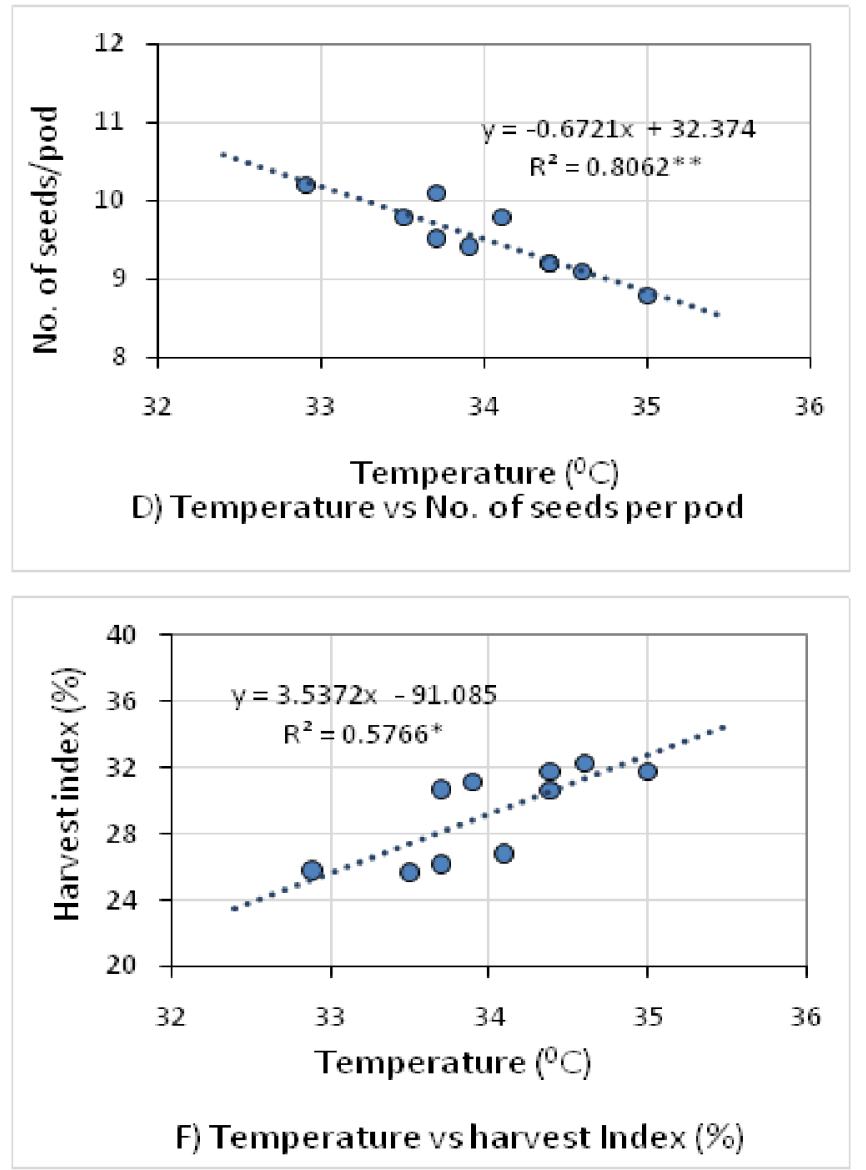

Fig-5: Relation between temperature and grain yield and yield attributes of green gram cultivars inside the TGT[ ** Regression significant at $\mathrm{P}=0.001, *$ Regression significant at $\mathrm{P}=0.005$ ]

Khattak et al. (2009) reported shedding of pods in green gram crop with increase in temperature. Morrison and Lawrol (1999) also reported that number of pods decreased with increase in temperature. Kumari and Varma (1983) have reported the adverse effect of elevated temperature on number of seeds per pod. Vara Parsad et al. (2013) opined that grain development in green gram is highly susceptible to high temperature stress. The effect of heat stress on yield and yield components might be attributed to the nitrate assimilation in legumes by lowering synthesis of ureides and decreasing levels and activities of nitrate reductase and glutamate synthase (Hungria and Vargas, 2000). The strong negative correlation of different yield components with temperature in the present studies is in agreement with the earlier studies. 


\section{Harvest index (HI) (\%)}

Under elevated temperature regimes during two crop years, harvest index (ratio of economic yield to the total biomass yield) was maximum for the cultivar ML-2037 (30.02\%) followed by ML 2056 (28.3\%), ML-818 (27.6\%) and PAU-911 (27.4\%) in decreasing order. Higher harvest index in a cultivar indicates its tolerance towards high temperature stress and is one of the most desirable traits to be considered while screening the tolerance of the cultivar towards heat stress. The data further revealed that harvest index (\%) was significantlyhigher under ambient temperature condition as compared to elevated temperature regimes. Among the temperature regimes, harvest index was increased by $14.7,28.9$ and $40.0 \%$ with increase in mean elevated temperature for two crop seasons by $3.9,4.3$ and $4.8{ }^{\circ} \mathrm{C}$, respectively. However, the interaction effect of the variety and elevated temperature regimes was non-significant.

\section{CONCLUSION}

The present study demonstrated the use of UV stabilized polythene sheet made tunnel of $30 \mathrm{~m}$ length, $5 \mathrm{~m}$ width and $3 \mathrm{~m}$ height as 'Temperature Gradient Tunnel' that could offer 3.3 to $5.2^{\circ} \mathrm{C}$ elevated temperature regime during monsoon season. The elevated temperature inside TGT throughout the growth period reduced crop phenological duration leading to early maturity of green gram. However, the response was cultivar specific. While the plant height inside the TGT positively correlated with temperature the branching showed the reverse trend. On the other hand, both plant height and number of branches per plant were higher in open condition.

Reduction in grain yield of green gram with rise in temperature is attributed to shortening of crop growth period, reduction in LAI and also decrease in yield parameters like pod per plant, seed per pod, 100-grain weight. Among the cultivars, ML-2017 was the most tolerant to high temperature stress, whereascv ML-1811 was the most susceptible one among the tested varieties.

The optimum ambient temperature for maximum yield is. $29.7^{\circ} \mathrm{C}$ as the yield decreased further with increase in temperature depending on cultivars type and degree of rise in temperature. However, the critical threshold limit of elevated temperature could not be ascertained with this experiment as the temperature gradient started with $3.3{ }^{\circ} \mathrm{C}$. The findings of this work will pave the way for further investigations. The future challenge is to create more temperature gradients in the lower side so that the critical temperature threshold limits for optimum yield of green gram can be ascertained.

\section{ACKNOWLEDGEMENT}

The Temperature Gradient Tunnel facility was developed under the Dept. of Science and Technology (DST), India sponsored PURSE project entitled "Mitigating the effect of Climate change on crop productivity". The use of the said facility for undertaking the crop experiments in this study is hereby acknowledged.

\section{REFERENCES}

Aggarwal, V.D. and Poehlman, J.M. (1977). Effects of photoperiod and temperature on flowering in green gram (Vignaradiata (L.)Wilczek). Euphytica, 26: 207219.

Araujo, S.S., Beebe, S., Crespi, M., Delbreli, B., Gonzaliz, E.M. and Gruber, V.(2015). Abiotic stress responses in legumes: strategies used to cope with environmental challenges. Crit. Rev. Plant Sci., 34: 237-280.

Bal, S.K. and Minhas, P.S. (2017). Atmospheric Stressors: Challenges and Coping Strategies. In: "Abiotic Stress Management for ResilientAgriculture”.'(Eds. P.S. Minhas et al.). pp. 9-50, Springer Nature Singapore Pte.Ltd.

Bal, S.K., Bhagat, K.P., Chowdhury, A.R., More, N., Suman, S. and Singh, H. (2018). Managing Photo-thermal Environment for Improving Crop Productivity. In: "Advances in Crop Environment Interaction". (Eds. S.K. Bal et al.). pp. 153-179, Springer Nature Singapore Pte Ltd. https://doi.org/10.1007/978-981-13-1861$0 \_6$

Bordeleau, L.M. and Prevost D. (1994).Nodulation and nitrogen fixation in extreme environments. Plant Soil, 161: 115125.

Challinor,A.J. and Wheller, T.R. (2008). Crop yield reduction in the tropics under climate change: Process and uncertainties. Agric. Forest Meteorol., 148: 343-356.

Hungria, M. and Vargas, M.A.T. (2000). Environmental factors affecting $\mathrm{N}_{2}$ fixation in grain legumes in the tropics, with an emphasis on Brazil. Field Crops Res., 65(2): 151-164.

Khattak, G.S.S., Saeed, I. and Muhammad, T. (2009). Flower shedding under high temperature in green gram (Vignaradiata (I).Wilczek). Pak. J. Bot.,41:35-39.

Kumari, P. and Varma, S.K. (1983). Genotypic differences in flower production/shedding and yield in green gram (Vignaradiata L.). Ind. J. Plant Physiol.,26: 402-405. 
Michelle, C. (2001-02). The effect of temperature on percentage of germination of green gram.www. Selah. K.12.wa.us/ soar/sciprp/2002/ Michelle/html

Morrison, J.I.L. and Lawlor, D.W.(1999). Interactions between increasing $\mathrm{CO}_{2}$ concentration and temperature on Plant growth.Plant Cell Environ., 22: 659-682.

Prabhjyot-Kaur., Harleen-Kaur., Harpreet-Singh. and Sandhu, S.S. (2019). Effect of elevated temperature regimes on growth and yield of rice cultivars under temperature gradient tunnel (TGT) environments. J. Agrometeorol., 21(3): 241-248.

Rainey, K.M. and Griffiths, P.P. (2005). Inheritance of heat tolerance during reproductive development in snap bean (Phaseolous Vulgaris L.). J. Amer. Soc. Hort. Sci., 130(5): 700-706.

Sadras, V.O. and Monzon, JP. (2006). Modelled wheat phenology captures rising temperature trends: Shortened time to flowering and maturity in Australia and Argentina. Field Crops Res.,99:136-146.

Singh, A., Phadke, V.S. and Patwardhan, A. (2011). Impact of drought and flood on Indian food grain production. In:
"Challenges and opportunities in Agro-meteorology". (Eds.S.D. Attri et al.), pp. 421-433, Springer Berlin Heidelberg.

Singh, D.P. and Singh, B.B. (2011). Breeding for tolerance to abiotic stresses in green gram.J. Food Legumes, 24: 8390.

Sinha, S.K. (1977). Food legumes: Distribution adaptability and biology of yield. In: Food and Agriculture Organisation of the United Nations, Plant Production and Protection Paper No. 3.pp. 124, Rome, FAO.

Tao, F., Yokozawa, M., Xu, Y., Hayashi, Y. and Zhang, Z. (2006). Climate changes and trends in phenology and yields of field crops in China from 1981-2000. Agric. Forest Meteorol., 138: 82-92.

Tzudir, L., Bera, P.S. and Chakraborty, P.K. (2014). Impact of temperature on reproductive development in Green gram (Vignaradiata L.) varieties under different dates of sowing.Int. J. Biol. Res., 5: 194-199.

Vara Parasad, P.V., Boote, K.J., Hartwell, A.J.L. and Thomas, J.M.G. (2013). Effect of elevated temperature and $\mathrm{CO}_{2}$ on seed-set and yield of kidneybean (Phaseolus vulgaris L.) Global Change Biol. J., 21: 710-721. 